\title{
FORMULASI MINUMAN HERBAL ANTIOKSIDAN JAHE MERAH (Zingiber officinale Rosc. var. rubrum)
}

\author{
Hendy Suhendy ${ }^{1 *}$, Vera Nurviana ${ }^{1}$, Defri Risviana ${ }^{1}$, Nur Alim Mahendra ${ }^{1}$, Aisyah \\ Shiddiqah Nasir', Irna Fitriani' ${ }^{1}$, Ani Suarsih', Nonin Nurnanengsih', Clarisa Kartika \\ Sanusi' ${ }^{1}$, Fahmi Muhamad Naser ${ }^{1}$, Winda Siti Wulandari', Dela leska Kaniaty', \\ Muhamad Rifky Fauzan' ${ }^{1}$, Arum Diah Pitaloka', Siti Nur Kasyifa Muhamad', Hisni \\ Nurul Fajri', Dikri Fadhlurrohman' ${ }^{1}$, Dini Agustiani' ${ }^{1}$, Livia Anggraeni' ${ }^{1}$, Anisa Nursilmi', \\ Resti Fizriani', Leti Nurlathifah', Windi Okta Milena', Ipah Rahayu', Trian Nur'aripin', \\ Salsabila Hanifah $\mathbf{O}^{1}$
}

${ }^{1}$ Kelompok Keahlian Biologi Farmasi, Program Studi S1 Farmasi, Sekolah Tinggi Ilmu Kesehatan Bakti Tunas Husada, Jl. Cololohan No. 36, Tasikmalaya, Jawa Barat, Indonesia

\section{Info Article}

Submitted :

05 Februari 2021

Revised :

30 Mei 2021

Accepted :

O6 Juli 2021

\section{Corresponding Author :}

Hendy Suhendy

Email :

hendysuhendy@stikes-

bth.ac.id

\section{ABSTRAK}

Prevalensi kasus Covid-19 di Indonesia sangat tinggi dan salah satu faktor mortalitasnya adalah penyakit komorbid yang diakibatkan karena tingginya radikal bebas didalam tubuh. Antioksidan dari luar diperlukan sebagai asupan untuk menghambat radikal bebas. Jahe merah merupakan sumber antioksidan alami yang sering digunakan dalam campuran minuman karena memiliki rasa pedas. Penelitian ini bertujuan untuk melakukan formulasi dan mengevaluasi aktivitas antioksidan produk minuman herbal jahe merah. Tahap pertama penelitian adalah preparasi simplisia, karakterisasi simplisia, ekstraksi simplisia jahe merah dan penapisan fitokimia ekstrak. Tahap kedua adalah formulasi minuman herbal, evaluasi produk dan evaluasi antioksidan produk menggunakan metode DPPH. Komposisi minuman herbal adalah $14,23 \mathrm{~mL}$ sari jahe , $57 \mathrm{~mL}$ susu UHT, 35,7 gram gula dan 143,07 mL air. Hasil penelitian menunjukkan bahwa secara organoleptik produk stabil selama satu hari, sedangkan nilai pH 5,8; viskositas 16 cp (100 rpm); homogen dan cukup baik untuk uji hedonik. Evaluasi antikoksidan menunjukkan nilai IC50 asam askorbat dan produk minuman berturut-turut sebesar $6,39 \mu \mathrm{g} / \mathrm{mL}$ dan $8,44 \mu \mathrm{g} / \mathrm{mL}$. Minuman herbal jahe merah memenuhi semua parameter standar dan minuman ini memiliki aktivitas antioksidan sangat kuat. Kata kunci: minuman herbal, jahe merah, antioksidan
Access this article

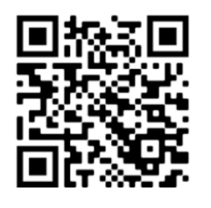

SCAN ME

\section{ABSTRACT}

The prevalence of Covid-19 cases in Indonesia is very high and one of the mortality factors are comorbid diseases caused by high free radicals in the body. Outside antioxidants are needed to inhibit the free radicals. Red ginger is a natural antioxidant that is often used in drink product because of the spicy taste. The objective of the study is to formulate and evaluate the antioxidant activity of herbal drink product of red ginger. The first steps of the research are simplicia preparation, simplicia characterization, extraction of red 
ginger simplicia and phytochemical screening of the extracts. The second steps are formulation of the herbal drink, product evaluation and antioxidant evaluation of the product using DPPH methods. The compositions of herbal drink are $14.23 \mathrm{~mL}$ of ginger extract, $57 \mathrm{~mL}$ of UHT milk, 35.7 grams of sugar, and $143.07 \mathrm{~mL}$ of water. The results showed that product organoleptically stable in one day while $\mathrm{pH}$ value of 5.8 , viscosity $16 \mathrm{cp}(100 \mathrm{rpm})$, homogeneous until the second day and good enough for the hedonic test. The evaluation of antioxidants showed that the $\mathrm{IC}_{50}$ values of asam askorbat and herbal drink products respectivelly were $6.39 \mu \mathrm{g} / \mathrm{mL}$ and $8.44 \mu \mathrm{g} / \mathrm{mL}$. Herbal drink of Red ginger meets all standard parameters and also it has very strong antioxidant activity.

Keywords: herbal drink, red ginger, antioxidant

\section{PENDAHULUAN}

Prevalensi kasus Covid-19 di Indonesia adalah sebanyak 104,432 dan kasus meninggal sebanyak 4,975 yaitu $4,8 \%$ sedangkan angka kematian kasus Covid-19 didunia update 5 Oktober 2020 yaitu sebanyak 26,5 juta kasus (Kemenkes, 2020). Faktor mortalitas dari Covid-19 ini diduga salah satunya adalah karena penyakit komorbid. Systematic review terhadap beberapa penelitian menyebutkan data klinis dari 41 pasien Covid-19, dan menunjukkan 13 (32\%) dari mereka memiliki penyakit yang mendasarinya, termasuk penyakit kardiovaskular, diabetes, hipertensi, dan penyakit paru obstruktif kronis. Temuan dari 138 kasus COVID-19, hasilnya menunjukkan bahwa 64 (46,4\%) di antaranya memiliki komorbiditas. Pasien yang dirawat di perawatan intensif unit (ICU) memiliki jumlah komorbiditas yang lebih tinggi $(72,2 \%)$ daripada mereka tidak diterima di ICU (37,3\%). Ini menunjukkan komorbiditas kemungkinan adalah faktor risiko membawa hasil yang merugikan (Yang, dkk. 2020).
Radikal bebas merupakan salah satu penyebab penyakit-penyakit komorbid dimana jika jumlahnya didalam tubuh sangat banyak, dapat berpotensi menonaktifkan berbagai enzim, mengoksidasikan lemak, dan mengganggu DNA tubuh sehingga terjadi mutasi sel yang merupakan awal timbulnya kanker dan mengakibatkan beberapa penyakit paru diantaranya bronchitis kronis, penyakit paru obseraktif menahun, emfisema, asma, fibrosis (Handayani, dkk. 2003).

Untuk menghambat radikal bebas yang berlebih didalam tubuh perlu adanya asupan antioksidan dari luar sehingga dapat mencegah penyakit yang disebabkan radikal bebas tersebut. Salah satu sumber antioksidan dari luar tubuh yang berasal dari alam adalah tanaman obat seperti jahe merah. Selaras dengan surat edaran Dirjen Pelayanan Kesehatan nomor HK.02.02/IV/2243/2020 bahwa perawatan secara mandiri dan benar merupakan hal yang bisa dilakukan masyarakat melalui pemanfaatan tanaman 
obat sebagai obat tradisional (Direktorat Jendral Pelayanan Kesehatan, 2020).

Jahe merah sering digunakan dalam campuran minuman karena memiliki rasa pedas yang sangat kuat sehingga manfaatnya untuk menghangatkan tubuh lebih terasa. Secara empiris jahe merah bermanfaat untuk meningkatkan daya tahan tubuh, mengatasai radang, batuk, luka, dan alergi akibat gigitan serangga. Secara ilmiah ekstrak rimpang jahe merah positif mengandung senyawa flavonoid, tanin, saponin, alkaloid dan terpenoid dan ekstrak ini memeiliki aktivitas antioksidan sangat kuat dengan nilai $I_{50} 10,35 \mu \mathrm{g} / \mathrm{mL}$ (Munadi, 2020). Oleh sebab itu, penelitian ini bertujuan untuk memformulasikan jahe merah menjadi produk minuman yang bukan hanya memenuhi aspek evaluasi sediaan tetapi juga memiliki khasiat antioksidan secara ilmiah sehingga diharapkan bisa menjadi produk alternatif sebagai langkah preventif dalam penanggulangan kasus Covid-19.

\section{METODE PENELITIAN}

\subsection{Alat dan Bahan}

Alat yang digunakan adalah kompor gas (Rinnai ${ }^{\circledR}$ ), timbangan kilogram (five goats $^{\circledR}$ ), timbangan analit $\left(\right.$ camry $\left.^{\circledR}\right)$, panci, kuvet, spektrofotometer (Genesys ${ }^{\circledR}$ ), mikropipet, mikroskop dan alat-alat lain yang lazim dipakai di labolatorium. Sedangkan bahan yang digunakan adalah jahe merah, gula merah, full cream (Ultra Milk $\left.{ }^{\circledast}\right)$, air, krolalhidrat, reagen mayer, reagen dragendorf, logam magnesium, asam klorida, amil alkohol, besi (III) klorida, gelatin, reagen liebermann-burchard, 1,1difenil-2-pikrilhidrazil (Sigma Aldrich), asam askorbat p.a (Sigma Aldrich), metanol p.a (Smart Lab), amonia, kloroform, eter.

\subsection{Preparasi Sari}

Jahe merah dibersihkan dari kotoran, dicuci dengan air mengalir, di kupas dari kulitnya, di tiriskan dengan cara di anginaanginkan. Selanjutnya di haluskan dengan cara diparut, dan sari jahe merah di perah dengan menggunakan kain (Desrayani, 2019).

\subsection{Karakterisasi Simplisia}

Pengujian parameter makroskopik simplisia segar rimpang jahe merah (Zingiber officinale var. Rubrum) meliputi warna, bentuk, rasa, bau, serta ukuran. Warna dan bentuk dari rimpang jahe diamati ditempat dengan pencahayaan yang cukup. Pengujian rasa dicoba dengan indra pengecap terhadap potongan kecil rimpang. Pengujian bau dilakukan dengan cara rimpang dicium baunya. Selanjutnya, dilakukan pengukuran panjang rimpang menggunakan penggaris.

Pengujian mikroskopik dilakukan dengan pengamatan fragmen-fragmen pengenal irisan melintang tipis jahe merah yang ditetesi kloralhidrat dibawah mikroskop.

\subsection{Skrining Fitokimia Sari Jahe Merah \\ Skrining fitokimia dilakukan} terhadap senyawa-senyawa golongan metabolit sekunder seperti flavonoid, tannin, saponin, kuinon fenol dan monoterpene.

\subsection{Pembuatan Minuman Herbal Antioksidan \\ Formula dibuat perbotol dalam 250} $\mathrm{ml}$. Sari jahe yang sudah di perah di diamkan terlebih dahulu untuk mengendapkan patinya. Kemudian sari jahe diambil dengan hati-hati sehingga patinya tidak ikut terambil. Sari jahe yang 
disiapkan yaitu sebanyak 14,23 ml, dimasukan kedalam wadah untuk dimasak dengan penambahan air sebanyak 143,07 $\mathrm{ml}$, kemudian ditambahkan gula sebanyak $35,7 \mathrm{~g}$ dan sambil diaduk sampai mendidih. Kemudian dinginkan, tambahkan susu sebanyak $57 \mathrm{ml}$. Masukan sari jahe di add sebanyak $250 \mathrm{ml}$.

\subsection{Evaluasi Minuman Herbal Jahe Merah}

Uji pH dilakukan untuk mengetahui nilai $\mathrm{pH}$ minuman herbal dibandingkan dengan nilai standarnya. Pengujian menggunakan $\mathrm{pH}$ meter dengan cara sampel minuman jahe merah dimasukan pada wadah. $\mathrm{pH}$ meter dinyalakan dengan menekan tombol on pada $\mathrm{pH}$ meter kemudian di celupkan pada sari dan produk minuman jahe merah secara bergantian setelah ditunjukkan angka pada $\mathrm{pH}$ meter. Tunggu hingga angka berhenti, kemudian dicatat $\mathrm{pH}$ yang tertera pada display digita/pH meter.

Uji Viskositas minuman menggunakan viskometer Brookfield dengan spindle no 2, karena secara fisik sudah terlihat bahwa sari dan produk jahe merah memiliki kekentalan yang rendah. Kecepatan perputaran spindel (rpm) yang digunakan adalah 10 rpm, 20 rpm, 30 rpm, 50 rpm, dan 100 rpm.

Uji densitas dilakukan terhadap minuman jahe merah menggunakan piknometer. Piknometer kosong, kemudian ditimbang (W0), kemudian filtrat yang dihasilkan dimasukan kedalam piknometer sampai batas volume $10 \mathrm{ml}$, kemudian ditimbang berat piknometer yang berisi filtrat (W1) (Desrayani, 2019).
Homogenitas diamati dari ada tidaknya gumpalan atau endapan pada minuman jahe merah yang sudah dikocok.

Uji stabilitas produk minuman diamati secara organoleptik pada tiga kondisi suhu yang berbeda yakni suhu ruang $\left(25-271^{\circ} \mathrm{C}\right)$, suhu dingin $10^{\circ} \mathrm{C}$, dan dibagian beku dengan suhu $4^{\circ} \mathrm{C}$ diamati perubahan yang terjadi.

Uji hedonik menggunakan sejumlah responden yang dimintai tanggapan pribadinya tentang kesukaan atau ketidaksukaannya terhadap produk minuman herbal jahe merah dalam bentuk skala hedonik.

\subsection{Evaluasi Antioksidan Minuman Herbal dan Asam Askorbat dengan Metode DPPH \\ Masing-masing sampel dibuat} beberapa konsentrasi, kemudian diambil 1 $\mathrm{mL}$ larutan sampel pada semua konsentrasi dan ditambahkan dengan 2 $\mathrm{mL}$ larutan DPPH $50 \mu \mathrm{g} / \mathrm{mL}$ (perbandingan volume 1:2). Campuran tersebut kemudian diinkubasi selama 30 menit dan diukur absorbansinya pada panjang gelombang $515 \mathrm{~nm}$. Pengukuran dilakukan sebanyak tiga kali pengulanagan. Metanol digunakan sebagai blanko, larutan DPPH $50 \mu \mathrm{g} / \mathrm{mL}$ sebagai kontrol dan asam askorbat sebagai pembanding.

Nilai IC50 ditetapkan melalui persamaan regresi linier dari kurva kalibrasi yaitu persentase peredaman sebagai sumbu y dan konsentrasi antioksidan sebagai sumbu $x$. Nilai IC50 dihitung dengan cara memasukkan nilai 50\% ke dalam persamaan regresi sebagai nilai $y$, kemudian dihitung nilai $\mathrm{x}$ sebagai konsentrasi IC50. 


\subsection{Analisis Data}

Data hasil pengujian antioksidan dinyatakan sebagai rataan $\mathrm{IC}_{50} \pm$ standar deviasi. Analisis varians dilakukan dengan prosedur ANOVA satu arah - post hoc Tukey (nilai $p<0,05$ ). Pengolahan analisis statistik ini dilakukan dengan menggunakan SPSS 16.0.

\section{HASIL DAN PEMBAHASAN}

\subsection{Hasil Preparasi Sari}

1,5 Liter sari jahe merah diperoleh dari hasil pemerahan 2,83 kg rimpang basahnya. Hasil ini sudah cukup banyak dan bisa diformulasikan kedalam $>100$ botol minuman dengan kapasitas $250 \mathrm{~mL}$.
3.2. Hasil Karakterisasi Simplisia

Pengamatan makroskopik dan mikroskopik dilakukan secara organoleptis terhadap rimpang jahe merah (Gambar 1) dan hasilnya dapat dilihat pada Tabel $\mathbf{1}$.

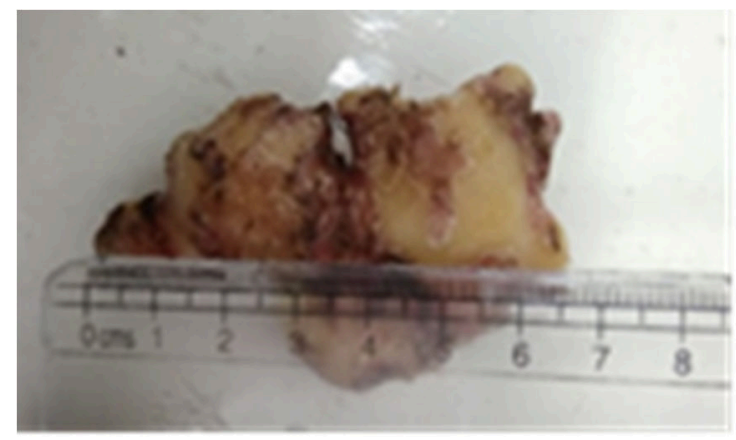

Gambar1. Rimpang jahe merah

Tabel 1. Hasil Uji Makroskopik dan Mikroskopik Simplisia Basah Rimpang Jahe Merah

\begin{tabular}{cccccc}
\hline Sampel & Warna & Bau & Rasa & Ukuran $(\mathbf{c m})$ & Fragmen Pengenal \\
\hline $\begin{array}{c}\text { Simplisia } \\
\text { Basah }\end{array}$ & Merah & $\begin{array}{c}\text { Khas } \\
\text { aromatik }\end{array}$ & Pedas & $4-11$ & $\begin{array}{c}\text { Amilum, } \\
\text { skelerenkim, parenkim, sel minyak, } \\
\text { berkas pengangkut }\end{array}$ \\
\hline
\end{tabular}

Tabel 1 menunjukkan bahwa sampel yang digunakan adalah benar rimpang jahe merah sesuai dengan yang tercantum pada Farmakope Herbal Indonesia Edisi II (Kemenkes, 2017).

\subsection{Hasil Skrining Fitokimia Sari Jahe Merah \\ Skrining fitokimia sari jahe merah} terhadap senyawa-senyawa metabolit sekunder dapat dilihat pada Tabel 2. Hasil ini sudah cukup banyak dan bisa diformulasikan kedalam $>100$ botol minuman dengan kapasitas $250 \mathrm{~mL}$.

\subsection{Hasil Karakterisasi Simplisia}

Pengamatan makroskopik dan mikroskopik dilakukan secara organoleptis terhadap rimpang jahe merah (Gambar 1) dan hasilnya dapat dilihat pada Tabel 2.

Tabel 2. Hasil Skrining Fitokimia Sari Jahe Merah

\begin{tabular}{ccc}
\hline Sampel & Golongan Senyawa & Hasil \\
\hline & Metabolit Sekunder & - \\
& Alkaloid & + \\
Sari rimpang jahe merah & Flavonoid & + \\
& Saponin & + \\
& Tanin & - \\
& Polifenol & + \\
\hline
\end{tabular}

Keterangan $\quad:+=$ Teridentifikasi , - = Tidak teridentifikasi 
Pada tabel diatas senyawa-senyawa golongan metabolit sekunder yang terkandung dalam sari rimpang jahe merah teruatam flavonoid diduga adalah kontributor utama aktivitas antioksidannya (Fidrianny, dkk. 2018).

\subsection{Hasil Pembuatan Minuman Herbal}

Formula minuman jahe merah terdiri dari sari jahe merah, susu full cream, gula aren dan air dengan perbandingan $1: 4: 2,5: 10$. Penambahan susu full cream setelah sari jahe dingin, bertujuan untuk mencegah rusaknya susu akibat adanya pemanasan pada suhu tinggi. Penambahan susu full cream juga bertujuan untuk menutupi rasa dari jahe merah yang kurang disukai terutama oleh remaja. Sebagai pemanis digunakan gula aren karena mengandung sukrosa kurang lebih $84 \%$ dibandingkan dengan gula tebu yang hanya $20 \%$, sehingga gula aren mampu menyediakan energi yang lebih tinggi dari gula tebu (Rumokoy, 1990). Penambahan gula aren juga berpengaruh terhadap sediaan dihasilkan, yaitu menghasilkan warna minuman menjadi lebih cerah (Rachman, 2009). Minuman sari jahe merah dibuat dalam kemasan $250 \mathrm{~mL}$ sehingga konsentrasi sari jahe merah pada tiap botol sebesar $14,23 \mathrm{~mL} / 250 \mathrm{~mL}$. Hasil pembuatan dan pengemasan dapat dilihat pada Gambar 2.

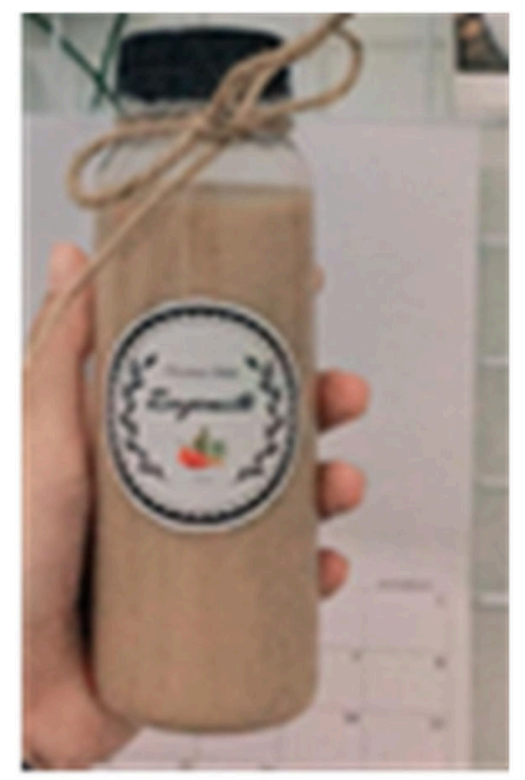

Gambar 2. Produk minuman herbal jahe merah

\subsection{Hasil Evaluasi Minuman Herbal Jahe Merah}

Evaluasi minuman herbal dilakukan untuk melihat nilai-nilai hasil pengujian parameternya memenuhi nilai standar atau tidak sehingga menunjukkan kualitas dari produk tersebut. Hasil evaluasi dapat dilihat pada Tabel 3.

Tabel 3. Hasil Evaluasi Minuman Herbal Jahe Merah

\begin{tabular}{ccc}
\hline Parameter & Hasil & Nilai Standar \\
\hline $\mathrm{pH}$ & $5,57 \pm 0,7$ & $\begin{array}{c}4-7 \\
\text { (Husen, 2015) } \\
\text { Viskositas }\end{array}$ \\
& $16 \mathrm{cp}$ & $>1 \mathrm{cp}$ \\
Densitas & $(100 \mathrm{rpm})$ & (Anggraini, 2016) \\
Homogenitas & 1,05 & - \\
Stabilitas & Tidak ada endapan & Homogen \\
Hedonik & Stabil secara organoleptic sampai hari-1 & - \\
pada suhu penyimpanan 4 ${ }^{\circ} \mathrm{C}$ & Panelis menyukai produk \\
\hline
\end{tabular}

Tabel 3 menunjukkan bahwa minuman herbal jahe merah memenuhi semua nilai parameter standar meskipun terdapat kekurangan dalam hal stabilitas bau rasa dan warna yang hanya bertahan dalam jangka waktu 1 hari pada suhu $4^{\circ} \mathrm{C}$. Pendeknya waktu stabilitas ini diduga dipengaruhi oleh tidak adanya 
penambahan zat pengawet sehingga memudahkan tumbuhnya mikroorganisme.

\subsection{Hasil Evaluasi Antioksidan Minuman Herbal dan Asam Askorbat dengan Metode DPPH}

Asam askorbat sebagai pembanding digunakan karena lebih praktis, aman, larut dalam air dan senyawa antioksidan alami yang memiliki aktivitas antioksidan sangat kuat jika dibandingkan dengan vitamin $\mathrm{A}$ dan vitamin E (Munadi, 2020). Pengujian aktivitas antioksidan menggunakan metode DPPH karena memiliki keuntungan dalam pelaksaannya karena metode yang sederhana, cepat, membutuhkan sedikit sampel dan mudah. Hasil pengujian dapat dilihat pada Tabel 4.

Tabel 4. Nilai I $\mathrm{I}_{50}$ Minuman Jahe Merah, Asam Askorbat dan Ekstrak Jahe Merah

\begin{tabular}{lcc}
\hline \multicolumn{1}{c}{ Sampel } & $\begin{array}{c}\text { Rataan IC } \\
(\boldsymbol{\mu g} / \mathbf{m L} \mathbf{)} \pm \mathbf{S D}\end{array}$ & $\begin{array}{c}\text { Kategori Antioksidan } \\
\text { (Molyneux, 2004) }\end{array}$ \\
\hline Asam askorbat & $6,39 \pm 0,02^{\mathrm{a}}$ & Sangat Kuat \\
Minuman Jahe merah & $8,44 \pm 0,02^{\mathrm{b}}$ & Sangat Kuat \\
Ekstrak jahe merah (Munadi, 2020) & $10,35 \pm 0,00^{\mathrm{c}}$ & Sangat Kuat \\
\hline
\end{tabular}

Keterangan $: \mathrm{a}-\mathrm{c}=$ huruf yang berbeda dalam satu kolom menunjukkan terdapat perbedaan bermakna $(p<0,05)$

Tabel 4 merupakan sajian analisis statistik dari data perbandingan $\mathrm{IC}_{50}$ antara minuman jahe merah, ekstrak jahe merah dan asam askorbat yang sudah diuji normalitasnya $\quad(p>0,05)$ Analisis menggunakan one-way ANOVA dan hasilnya menunjukkan adanya perbedaan signifikan antar kelompok $(p<0,05)$. Uji Post Hoc menggunakan Tukey hasilnya pun menunjukkan perbedaan signifikan semua pasangan kelompok $(p<0,05)$. Secara angka nilai $\mathrm{IC}_{50}$ kelompok asam askorbat lebih rendah dari pada jahe merah dalam bentuk produk minuman herbal ataupun bentuk ekstraknya, namun secara kategori antioksidan ketiga kelompok sama-sama memiliki aktivitas antioksidan sangat kuat sehingga bisa dikatakan pemilihan formulasi dan bentuk produk herbal antioksidan jahe merah sudah sesuai.

\section{KESIMPULAN}

Minuman herbal jahe merah memenuhi semua parameter standar dan minuman ini memiliki aktivitas antioksidan sangat kuat.

\section{UCAPAN TERIMA KASIH}

Penulis mengucapkan terima kasih kepada Kaprodi S1 Farmasi STIKes Bakti Tunas Husada apt. Ira Rahmiyani, M.Si. atas dukungan moril dan materil dalam pelaksanaan penelitian ini.

\section{DAFTAR PUSTAKA}

Anggraini DN, Radiati LE dan Purwadi., 2016. Penambahan Carboxymethyle Cellulose (CMC) pada minuman Madu Sari Apel Ditinjau dari Rasa, Aroma, Warna, pH, Viskositas dan kekeruhan, Jurnal IImu dan Teknologi Hasil Ternak, 11(1): 59-68. Retrieved November 18, 2020

Danusantoso H., 2020. Peran radikal bebas terhadap beberapa penyakit paru, $J$ Kedokter Trisakti, 22(1): 31-26

Desrayani H., 2019. Pembuatan Minuman Instan Jahe Merah (Zingimber officinale var. Rubrum). Sumatera Utara: 
Universitas Muhamadiyah Sumatera Utara.

Direktorat Jendral Pelayanan Kesehatan., 19 Mei 2020. Surat Edaran Nomor HK.02.02/IV/2243/2020 Tentang Pemanfaatan Obat Tradisional Untuk pemeliharaan kesehatan, Pencegahan Penyakit dan Perawatan kesehatan.

Fidrianny I, Suhendy H dan Insanu M., 2018. Correlation of phytochemical content with antioxidant potential of various sweet potato (Ipomoea batatas) in West Java, Indonesia, Asian Pacific Journal of Tropical Biomedicine, 8(1): 25-30

Handayani V, Ahmad AR dan Sudir M., 2014. Uji Aktivitas Antioksidan Ekstrak Metanol Bunga dan Daun Patikala (Etlingera elatior (Jack) R.M.Sm) Menggunakan Metode DPPH, Pharm Sci Res, 24072354.

Husen RW, Yamlean P dan Citraningtyas G., 2015. Formulasi dan Evaluasi sirup Ekstrak Daun Sidaguri (Sida rhombifolia L.), Pharmacon, 4(3): 134-138.

Kemenkes., 2017. Farmakope Herbal Indonesia Edisi II, Jakarta: Kementerian Kesehatan Republik Indonesia.
Kemenkes., 2020. Covid-19 - Infeksi Emerging. https://infeksiemerging.kemkes.go.id/

Munadi R., 2020. Analisis Komponen Kimia dan Uji Aktivitas Antioksidan Ekstrak Rimpang Jahe Merah (Zingiber officinale Rosc. Var Rubrum), Cokroaminoto Journal of Chemical Science, 2(1): 1-6.

Molyneux P., 2004. The Use of the stable Free Radical Dipheneylpicrylhidrazyl (DPPH) for Estimating Antioxidant Activity, Journal of Sciences and Tecnology, Songklanakarin J. Sco. Technol, 26(1): 211-219.

Rachman B., 2009. Farmers' Characteristics and Palm Sugar Marketing in Banten. Forum Penelitian Agro Ekonomi, 27(1):53-60

Rumokoy MMM., 1990. Manfaat Tanaman Aren (Arenga pinnata), Buletin Balitka, No.10: 21- 28. Balai Penelitian Kelapa. Manado

Yang J, Zheng Y, Gou X, Pu K, Chen Z, Guo Q, Ji R, Wang H, Wang Y dan Zhou Y., 2020. Prevalence of comorbidities in the novel Wuhan coronavirus (COVID-19) infection: a systematic review and metaanalysis, International journal of infectious diseases. 